\title{
Forming long-term competitiveness of a mineral sector as part of economy innovative development strategy
}

\author{
Natalia Lomakina ${ }^{1^{*}}$ \\ ${ }^{1}$ Economic research institute of Far East division of Russian Academy of Sciences, Khabarovsk, \\ Russia
}

\begin{abstract}
The research was focused on the processes of structural diversification in a Far Eastern mineral sector and aided in obtaining the characteristics of new market position and space specializations in the mineral-raw complex of the region. It illustrates its influence on the dynamics of investments in the region. It highlights the high value of the mineral sector in Far Eastern federal district, its stable competitive positions in the regional and national economy. It shows the conditions of long-term competitiveness of the mineral raw complex of Far East in the national and foreign economies (these conditions were formed as part of foresight-forecast for the development of Pacific Russia up to 2050). The research also gives predictive estimates of possible ways of the structure and dynamics of long-term development of mineral-raw complex of Russian Far East. Key words: Mineral sector, foresight-forecast, synthesis of economic and technologic forecasts, Far East
\end{abstract}

\section{Introduction}

The national model of development through innovation that is being designed in Russia nowadays implies the transition from commodity-based economy to knowledge-based economy. In addition, the announced desire of the country to move to development through innovation allows for the continuation of the intensive development of natural resources. In fact, the exploitation of natural resources (in particular mineral-raw resources) in foreseeable future remains the source of means for the innovative transformation of the national economy.

This situation actualizes the issues of revealing the opportunities and characteristics of the perspective development of resources regions. An example of a large macro-region of resource specialization is Far East of Russia that is characterized by the abundance of natural resources and the development of resource complexes (particularly mineral-raw complex and fuel-power complex) that are the branches of national specialization.

The opportunities of perspective development for the region are alternative: either constructing a proving ground in the southern part of the Russian Far East, or moving to the concept of industrial diversification on the basis of exploiting the brand-new technologies,

\footnotetext{
${ }^{*}$ Corresponding author: lomakina@ecrin.ru
} 
connected with specific resources and conditions of Far East (a variant of "new industrialization") [1]. These kinds of activity also include the sector of national specialization of the region - extraction of mineral resources. But is Far Eastern mineral sector ready for such challenges? And what are the prospects of its long-term competitive development? What are the chances to maintaining traditional raw-material base and forming innovative-technological chains "extraction of new mineral-raw material inventing new products - forming new branches of mineral-raw complex"? These issues are studied in the article.

\section{Theory of experimental research}

The research on the theoretical and methodic issues of the contribution from the natural resources (particularly mineral resources) into socioeconomic development [2-7], quantitative evaluation for economic systems of various levels [8-12] not only remains acute, but also moves to a newer theoretical-methodic level [13-18 et al].

The issues of forming and elaborating a conceptual apparatus, applying new methods to estimate the interconnection "resource sector - resources region" are discussed in the works $[14,15,17,18$ et al]. This method aids in revealing and estimating new factors of forming "return" trajectory of the development of mineral resources in the resources regions. "Instead of fading and exhausting the economic potential ... resources region (as a result of exhaustion ... of "conventional" reserves of mineral resources) discussion can be focused on "return" trajectory - development and use of previously "overlooked" mineral-raw resources and "unnoticed" sources of "unconventional" kinds of raw material. In addition, the factors leading to the transition to the "return" trajectory are not only the technologies, but also the new quality of institutional environment" [14, p. 12].

The issues of the change in the canonical scheme of the development of mineral resources of the region - transition from fading to constant development through innovation - are acute for raw-material-rich territories of the Russian Far East, examined in the article. At present, they are also characterized by the growth of technological availability of mineral resources, development of "old" deposits under new technological parameters [19].

One of the main aspects of the problem is the consideration of the effective of resources projects and their contribution to the development of the region. These issues are the subjects of such branches of research as resource economy, economy of natural resource use, regional economy, spatial economy; effectiveness of investments, and particularly the investments to public sphere [20-22], natural resource rent, estimation of multipliers and system effects of natural resource projects [23-25 et al] and their regional localization [e.g. $11,14,15]$.

The scientific value of such researches lies in the adaption of various theoretical approaches and practical implementation of the methods of estimating the interconnection "resource sector - resources region" for certain territories in the conditions of forming innovative strategies of economic growth.

\section{Results and discussion}

The determining role of the natural resources in the economic development has been the distinctive feature of the Russian Far East for all the time of its development [11]. Far Eastern Federal District is the center of all nationwide reserves and almost $100 \%$ extraction of diamonds and tin, over $1 / 3$ reserves of gold and silver (45 and 65\% extraction, respectively), almost $80 \%$ production of tungsten concentrate and $100 \%$ extraction of antimony [26]. The research of structural diversification (industrial and territorial) in the 
mineral sector of Far Eastern District has shown that the most important changes were the following:

- $\quad$ significant decrease (naturally expressed) in the extraction of such metals as tungsten $(43.3 \%$ in 2015 , compared to 1990$)$, lead $(37.3 \%)$ zinc $(21.4 \%)$, tin $(9 \%)$, and copper $(7 \%)$;

- beginning of forming new industrial specializations of mineral-raw complex of Far East: extraction of raw material for the production of nickel and cobalt (Kamchatka Krai), titanomagnetite concentrate (Amur Oblast), and iron ore concentrate (Jewish autonomous oblast);

- $\quad$ confirmed value of precious metals as "structural leader" of the mineral sector

- change in the internal structure of gold mining in the region: in the 1990's, gold mining from placer deposits prevailed, and after 2010 , over $70 \%$ of gold in the region is extracted from primary deposits;

- $\quad$ growth in the technological availability of the resource base of gold mining in Far Eastern district that was driven by major companies entering the region and developing new technologies of estimating, extracting, and processing the mineral resources (e.g. overestimation of the deposit "Natalka", autoclave technologies, etc.)

However, with the presence of a number of positive changes, the main result of the changes in the industrial structure of Far Eastern mineral-raw complex is its significant narrowing and intensification of mono raw material nature of this sector.

As far as the territorial structure is concerned, the role of northern regions has remained important, (such resgions as Yakutia, Magadan Oblast and Chukotka Autonomous Okrug). They still produce $4 / 5$ products of the complex. In the southern part, with saving its share in the structure, was subject to significant interzonal changes in 2016, compared to 1990: sudden decrease of the share in Primorsky Krai (6,4 times) with the increased contribution from Khabarovsk Krai (1,3 times) and Amur Oblast (1,2 times). The share of mineral-raw complex in the industrial structure has been increased as a whole in Far Easter District from $14-15 \%$ in the 90 's to almost $30 \%$ by 2016 . The role of the mineral sector in Far Easter District keeps its strategic importance in the national economy.

One of the conditions of economic growth is investment activity. One of the indicators of investments quality can be their structural proportion between investments into rawmaterial and non-raw-material spheres of regional economy. We have calculated such structural proportions that were formed in the economy of Far Easter district in general and in separate subjects of the Russian Federation in the period from 2005 to 2006 years (table 1). The analysis shows that the share of investments to the extraction of mineral resources in the Russian Federation in the overall structure of investments into the basic capital has been 1,44 times increased (reaching almost $20 \%$ of all investments). In Far Eastern District, this growth was 1,87 times, and the share of investments to Far Eastern District reached $40 \%$ in the basic capital.

In the group of far eastern regions with conventional mineral-raw specialization, the share of investments into the raw-material sector in the examined period has been growing, with aided in the growth of competition of this activity in the overall structure of the industry (table 1). Significant growth of the share of investments to mineral-raw complex is noticeable in Kamchatka Krai, Jewish autonomous oblast, which leads these subjects of the Russian federation to the regions with mineral-raw specialization.

The dynamics show that for the majority of the far-eastern subjects of the Russian Federation, investments into mineral-raw complex are the basis of investment activity in the region. In confirms the high competitiveness of the mineral sector, although such a structure of investments forms the basis for the future "raw-material" image of Far Easter economy. 
Table 1. Investment activity of the mineral-raw complex of in Far Eastern district

\begin{tabular}{|c|c|c|c|c|}
\hline \multirow{2}{*}{} & \multicolumn{2}{|c|}{$\begin{array}{c}\text { Share of «mineral } \\
\text { resources extraction } \\
\text { without fuel-power } \\
\text { resources» in industry }\end{array}$} & $\begin{array}{c}\text { Share of investments } \\
\text { to the extraction of } \\
\text { mineral resources in } \\
\text { the overall structure } \\
\text { of investments into } \\
\text { the basic capital, \% }\end{array}$ \\
\cline { 2 - 5 } & 2005 & 2016 & 2005 & 2016 \\
\hline Russian Federation & 2,8 & 3,0 & 13,4 & 19,3 \\
\hline Far Eastern district & 31,2 & 29,6 & 21,0 & 39,3 \\
\hline Republic of Sakha & 63,4 & 51,7 & 45,5 & 51,2 \\
\hline Magadan Oblast & 67,5 & 83,6 & 14,1 & 69,5 \\
\hline Chukotka autonomous okrug & 31,7 & 88,4 & 0,3 & 36,4 \\
\hline Kamchatka krai & 11,8 & 16,4 & 4,4 & 21,9 \\
\hline Jewish autonomous oblast & 5,0 & 13,3 & 0,3 & 36,4 \\
\hline
\end{tabular}

Source: calculations from the official data of Rosstat.

The issue of the conditions of long-term competitiveness of the material-raw complex in Far Eastern District in the national and foreign economies (particularly southwestern parts of Asia) becomes legitimate. Estimation of the opportunities of the long-term development of the mineral-raw complex, its perspective role in the regional and national economy was among the most pressing issues in the formation of foresight forecast of the development of Pacific Russia til 2050 [1]. "Inventory cut" of fundamental and applied results of the researches in the institutes Far East division of the Russian Academy of Sciences in the field of mineral resources has shown that the opportunities of forming innovationtechnological chains "extraction of new kinds of minerals - invention of new products formation of new branches in the mineral-raw complex" in Far East (until 2050) will be based on:

- development of new unconventional kinds and sources of mineral raw material;

- widespread introduction of complex processing of multicomponent and refractory ores;

activation of industrial development of ore-placer waste of mining industry

formation of new mining regions within Far East.

In the perspective spatial structure of the mineral raw complex, leading positions are still held by Republic of Sakha, Magadan and Amur oblasts, Chukotka autonomous okrug. The role of Khabarovsk Krai, Kamchakta Krai and Jewish autonomous Oblast will be significantly increased in the structure of the regional mineral sector. One of the leading branches of Far Eastern economy will be the extraction of precious metals and diamonds. The development of mining and extraction of base metals in Far Eastern District is connected with the development of new deposits of copper and polymetallic ores (including those containing precious metals), antimony, niobium, rare earth metals, as well as vanadium-containing, titanomagnetite deposits. With the relevant level of production of the mineral raw-material base, there are reasons to count not only on the reservation and growth of the complex in conventional sub-branches (table 2), but also on the formation of new productions in its structure.

Table 2. Predictive estimates of production output of the mineral-raw complex of Far East

\begin{tabular}{|l|l|l|l} 
Types of production & 2015 & 2025 & 2050
\end{tabular}




\begin{tabular}{|c|c|c|c|}
\hline Gold, tons & 117,8 & $76-150$ & $45-240$ \\
\hline Silver, tons & 1418,2 & $1000-1500$ & $230-1700$ \\
\hline Lead, thousand tons & 12,3 & 24 & 24 \\
\hline Zinc, thousand tons & 22,2 & 35 & 35 \\
\hline Copper, thousand tons & 1,6 & $50-100$ & Н.д. \\
\hline Tungsten, thousand tons & 2,6 & $3,5-4,5$ & Н.д. \\
\hline Nickel, thousand tons & 4,6 & $20-25$ & Н.Д. \\
\hline Titan (dioxide), tons & - & $10-15$ & 152,0 \\
\hline Berrylium (dioxide). tons & - & 100,0 & 150,0 \\
\hline Ferriferous ores , concentrate million & 2,9 & $30-45 / 10-20$ & $65 / 20$ \\
\hline tons & 5,0 & 400,0 & 500,0 \\
\hline Manganese ores, thousand tons & &
\end{tabular}

Source: [26], [1, p. 341].

Thus, it was possible to obtain the estimates of scientific-technologic opportunities of the mineral sector of Far East in the form of results of fundamental and applied researches. To determine the opportunities of long-term development of the sector and its competitiveness, these results need to be "converted" into economic parameters, scenarios and and institutional-economic conditions for such development need to be formed and estimated.

\section{Conclusions}

As part of the implementation of these goals, the article was focused on the processes and achievement of the estimate of structural diversification (industrial and territorial) in the mineral sector of Far East. It also characterizes the investment activity in the mineral-raw sector, and illustrates its high value, stable competitive positions in the regional and national economy. It shows the conditions for long-term competitiveness of the mineralraw sector in the national and neighboring economies, formed as part of the foresightforecast of the development of Pacific Russia until 2050. The most important conditions, along with the productive and technological conditions, providing the stable and competitive development of the mineral sector of Far East in the long-term prospect, are institutional conditions for forming its "new image"

\section{References}

1. Synthesis of scientifically technical and economic forecasts: Pacific Russia -2050 / edited by P.A. Minakira, V.I. Sergienko, Vladivostok: Dalnauka, pp. 912. (2011).

2. Auty R. Sustaining Development in Mineral Economies. The resource curse thesis. N.Y., Routledge. p. 272. (1993).

3. Auty, R. Natural Resources, the State and Development Strategy // Journal of International Development. 9. pp. 651-663. (1997).

4. Gylfason, T., Herbertsson T., Zoega G. Macroeconomic Dynamics, 3. pp. 204225. (1999).

5. Sachs, J., Warner A. Natural Resource Abundance and Economic Growth / NBER Working Paper 5398, Cambridge, Massachusetts. p. 54. (1995).

6. Barbier E.B. Natural Resources and Economic Development. Cambridge University Press. p. 410. (2005). 
7. Harmonious Development Through Innovation 2008. CCICED Annual Policy Report. Peking: China Council for International Cooperation on Environment and Development. p. 317. (2009).

8. E.V. Ryumina, A.M. Anikina, Problems of prognostication. 5. P.106-125. (2007). http://www.ecfor.ru/fp/index.php?pid=archive.

9. N.N. Mikheeva, Evaluating Russian Far East's Resource Sector Based on "Input Output" Tables // Spatial Economy. 1. pp. 72-86. (2006).

10. M.N. Uzyakov. Problems of prognostication. 2. pp. 3-18. (2011).

11. N.V. Lomakina, Mineral Sector of Russian Far East: Potential for Development. Edited by P.A. Minakir. Russian Academy of Sciences, Far Eastern Division, Economic Research Institute. Khabarovsk city. p. 240 (In Russian). (2009).

12. D.S. Kuznetsov. Problems of development of the territory. 6 (92). pp. 68-82. (2017).

13. O.S. Anashkin, V.A. Kryukov. Mineral resources of Russia. Economy and management. 1. pp. 24-33. (2015).

14. Resources Regions in a "New Reality". Edited by V.V. Kuleshov. Novosibirsk: Institute of Economics and Industrial Engineering SB RAS. p. 308 (In Russian). (2017).

15. Mineral Resource Sector of the Asian Part of Russia: How to Ensure the Social and Economic Impact. Edited by V.V. Kuleshov. Novosibirsk: Institute of Economics and Industrial Engineering SB RAS. p. 352 (In Russian). (2015).

16. S.V. Doroshenko, A.G. Shelomentsev. Modern technologies of management.. 3 (51). (2015). Article number: 5106. Date issued: 2015-03-08. Access mode: http://sovman.ru/articl/5106/

17. V.A. Kryukov, E.O. Pavlov, Integral estimation of the efficiency of subsoil use systems (comparative evaluation) // Mineral resources of Russia

18. A.K. Belan, V.V. Schmat, The analysis of the influence from resource and nonresource factors on the growth of economy in Tomsk Oblast with the help of cognitive approach // Vestnik NGU. Series: socioeconomic sciences. 15 (1). (2015).

19. N.V. Lomakina. Spatial Economy. 1. pp. 59-82. (2018). DOI:10.14530/se.2018.1.059-082.

20. O.S. Nagaeva. Regional economy and management: electronic scientific journal. 4 (48). Art. No.4804. Date issued: 2016-11-05. Available at: http://eee-region.ru/article/4804/

21. E. N. Sindyashkina. Problems of prognostication. 1. pp. 140-147. (2010).

22. T. S. Novikova, The analysis of social efficiency of investment projects. Novosibirsk: Institute of Economics and Industrial Engineering of the Siberian Division of RAS. pp. 221. (2005).

23. N.N. Mikheeva, T.S. Novikova, V.I. Suslov. Problems of prognostication. 4. pp. 78-90. (In Russian). (2011).

24. A.A. Shirov, A.A. Yantovsky. EKO. 2. pp. 40-58. (In Russian). (2011).

25. Gunton T. Regional Studies. 37. P.505-519. (2003).

26. Vologin V.G., Lazarev A.V.. The current status and prospects of the development of the mineral-raw complex in Far Eastern Federal District. Materials from the forum Minex-DV. Magadan, 2016. http://minexforum.com/wp-content/uploads/2016/07/1.1.1Vologin-V.G.-Dalnedra Sostoyanie-i-perespektivy-razvitiya-min-syr-bazy-DFO.pdf. Date of access: 03.11.2017

27. A.I. Khanchuk, N.V. Lomakina, V.V. Ivanov. Vestnik DVO RAN. 5. pp. 113-121. (2012). 